\title{
Ethnobotany of tree ferns in Pasir Menyan Hamlet, Sukamandi Village, Subang, West Java, Indonesia
}

\author{
SURYANA, JOHAN ISKANDAR, PARIKESIT, RUHYAT PARTASASMITA \\ Department of Biology, Faculty of Mathematics and Natural Sciences, Universitas Padjadjaran. Jl. Raya Bandung Sumedang Km. 21, Jatinangor, \\ Sumedang 45363, West Java, Indonesia. Tel./fax.: +62-284-288828. `email: ruhyat.partasasmita@unpad.ac.id; rp2010rikkyo@gmail.com
}

Manuscript received: 10 September 2018. Revision accepted: 20 October 2018.

\begin{abstract}
Suryana, Iskandar J, Parikesit, Partasasmita R. 2018. Ethnobotany of tree ferns in Pasir Menyan Hamlet, Sukamandi Village, Subang, West Java, Indonesia. Biodiversitas 19: 2044-2051. Tree ferns are plants that grow mostly in the highlands, such as in the forest area of Tangkuban Perahu Mountain, Subang, West Java, Indonesia. The existence of tree ferns and their population are threatened, along with forest damage and over-exploitation. The present study was directed to examine the local knowledge of the community around the forest area of Mount Tangkuban Perahu in term of local names, utilization, suitability to grow, and conservation efforts of tree fern. This research was conducted in Pasir Menyan Hamlet, Sukamandi Village, Subang, West Java in March-June 2017. The method used in this study was mixed-method, a combination of qualitative and quantitative, while some field techniques, including observation, semi-structured interviews, structured interviews, and botanical survey of tree ferns were carried out. The results of the study showed that it was recorded 8 landraces of tree fern were recognized by informants, namely pakis tihang, pakis sieur, bagedor, pakis minyak, pakis payung, pakis cempor, pakis bulu, and sijabrig. In terms of local knowledge on tree ferns, people with ages 50-59 years old recorded a right a higher percentage of tree ferns than the children and younger people. Regarding education, the result showed that a low level of education had the highest level of knowledge of local names and utilization of tree ferns as vegetables, ornamental plants, growing media, and for handicrafts because of they still intensive interaction with forest ecosystem and tree ferns. On the basis conservation of tree ferns, the rural people of Sundanese people have a tradition to prohibit (pamali) to cut forest on the river bank, open slopes, closed forests, damaged forest areas, and in the valleys. In addition, traditional conservation practice on tree ferns has recorded, for example, rural people of Pasir Menyan Hamlets have traditional prohibited to open sacred forest, including to take of tree ferns. $\square$
\end{abstract}

Keywords: Ethnobotany, diversity, conservation, utilization of tree ferns

\section{INTRODUCTION}

Tree ferns have a tree-like appearance with strong and tall stems up to $15 \mathrm{~m}$ or more. Tree ferns are members of Cyatheales which have 8 families and 16 genera and are often found in tropical and sub-tropical regions (Large and Bragins 2004; Tjitrosoepomo 2001; Ramirez et al. 2011). Based on Holtum's (1965), there are 13 species of tree ferns from the family of Cyatheaceae in West Java. Tree ferns are widely used for various purposes both directly and indirectly (Efendi et al. 2013; Iskandar 2018). Direct functions of tree ferns, such as Cyathea junghuhniana is predominantly used for construction pole (Rahayu et al. 2006) and Cibotium barometz is used as medicine (Praptosuwiryo et al. 2011), while indirect functions, including a component of forest vegetation, has ecological functions for producing oxygen $\left(\mathrm{O}_{2}\right)$, microclimate stabilization, fauna habitats, and hydrological regulation (van Steenis 2006).

The existence of the Mount Tangkuban Perahu forest as natural ecosystem provides various ecological and sociocultural functions, including retention of soil, regulation of run-off, stabilization of climate, a source of non-forest products, animal habitat, a source of knowledge, education, and recreation (Jacobs 1981). One potential found in the forest area of Mount Tangkuban Perahu is the existence of tree ferns. However, along with the destruction of forests and the over-exploitation, the population of tree ferns have begun to decline. Forest damage continues to occur from year to year including damage to forests in conservation areas (Partasasmita 2009; Partasasmita et al. 2016). Based on data on the development of species of forest disturbance and damage to conservation areas in the Central Office of West Java KSDA in 2011-2016, the four most influential aspect of forest damage were caused by forest fires (300.57 ha), wild agriculture (267 ha), illegal settlements (206.79 ha), and encroachment (23.77 ha) (BBKSDA West Java 2016).

Forest damage and the threat of extinction of tree ferns are closely related to socio-economic aspects of the population and institutional management of forest areas and species conservation, as the parties utilize tree ferns. The use and preservation of tree ferns contribute to improving the level of welfare and maintaining local knowledge (Whitten et al. 1999). In order to develop the potential of tree ferns, special ethnobotany studies are needed. Ethnobotany studies human interaction with plant resources (Anderson et al. 2011; Pei 2013), and its role is crucial for the conservation of forest plants (Pei 2013). Srivastava (2007) reports that ethnobotany is currently an important part of research and development of resource management, conservation of gene diversity, and socioeconomic development of an area. Ethnobotany also developed into an interdisciplinary science that examines 
human relations with plant natural resources and their environment. The approach that is often used in ethnobotany research is the emic approach, exploring and getting knowledge data of an object that is observed based on their perspective and terms (Iskandar 2012), which is then known as local knowledge.

Local knowledge has its benefits in people's lives, developing because of the need to maintain and sustain life by following the situation, conditions, abilities, and values that are lived in the community. In other words, local knowledge is part of a wise way of life to solve all the problems faced by life. Because of local knowledge, they can carry on their lives, even going on in sustainable development (Permana 2010). Local knowledge of people living around the forest is usually obtained from generation to generation from their ancestors. The delivery and development of inheritance are generally through three stages, namely the learning process from the older generation to the next generation, sharing knowledge with the same age group, and the adult group. Learning is based on experience and trials and ultimately is owned by each as traditional knowledge (Soepartinah 2013). The delivery and inheritance of knowledge are what causes people around the forest area to have detailed knowledge of a plant. The rural people of Pasir Menyan Hamlet, Sukamandi Village, Subang, West Java, Indonesia have local knowledge on forest plants, including tree ferns traditionally based on three stages, namely parental, peer, and individual learning. Parental education is traditional learning process of children from their parent or older brothers or vertical cultural transmission. The peer learning is learning process local knowledge on the phase of adolescent among peer groups or horizontal cultural transfer, while the individual learning carried by own rural people of each household when after adulthood (Iskandar and Iskandar 2005).

Research on local knowledge has been widely carried out, but not many foci on tree ferns. Praptosuwiryo et al. (2011) reported uses of Cibotium barometz as an ornamental plant in Harau District, West Sumatra. Meanwhile, Handayani and Hartini (2003) presented that residents of Ciapus area, Bogor, West Java use Cyathea contaminans tree ferns as planting media for species of Anthurium spp., Piper spp., Platycerium spp., Adiantum spp., and other species of ferns. In contrast to previous studies, This aim of study was to assess on ethnobotany on tree ferns related to their diversity, utilization, and conservation of trees fern.

This study was focused on local knowledge of Sundanese rural people of Pasir Menyan Hamlet, Sukamandi Village, Subang, West Java, Indonesia, on botany of tree ferns. The hamlet was chosen because most people who reside in this hamlet have strongly interacted with forest ecosystem intergeneration and have local knowledge on various forest plants, including tree ferns.

\section{MATERIALS AND METHODS}

\section{Area study}

The research was carried out in Pasir Menyan Hamlet, Sukamandi Village, Sagalaherang Sub-district, Subang District, West Java Province, Indonesia in March-June 2017. Sukamandi Village is one of the areas directly adjacent to the Mount Tangkuban Perahu, that located at 6 44 "45,26" S and 107037’27,22’E (Figure 1).
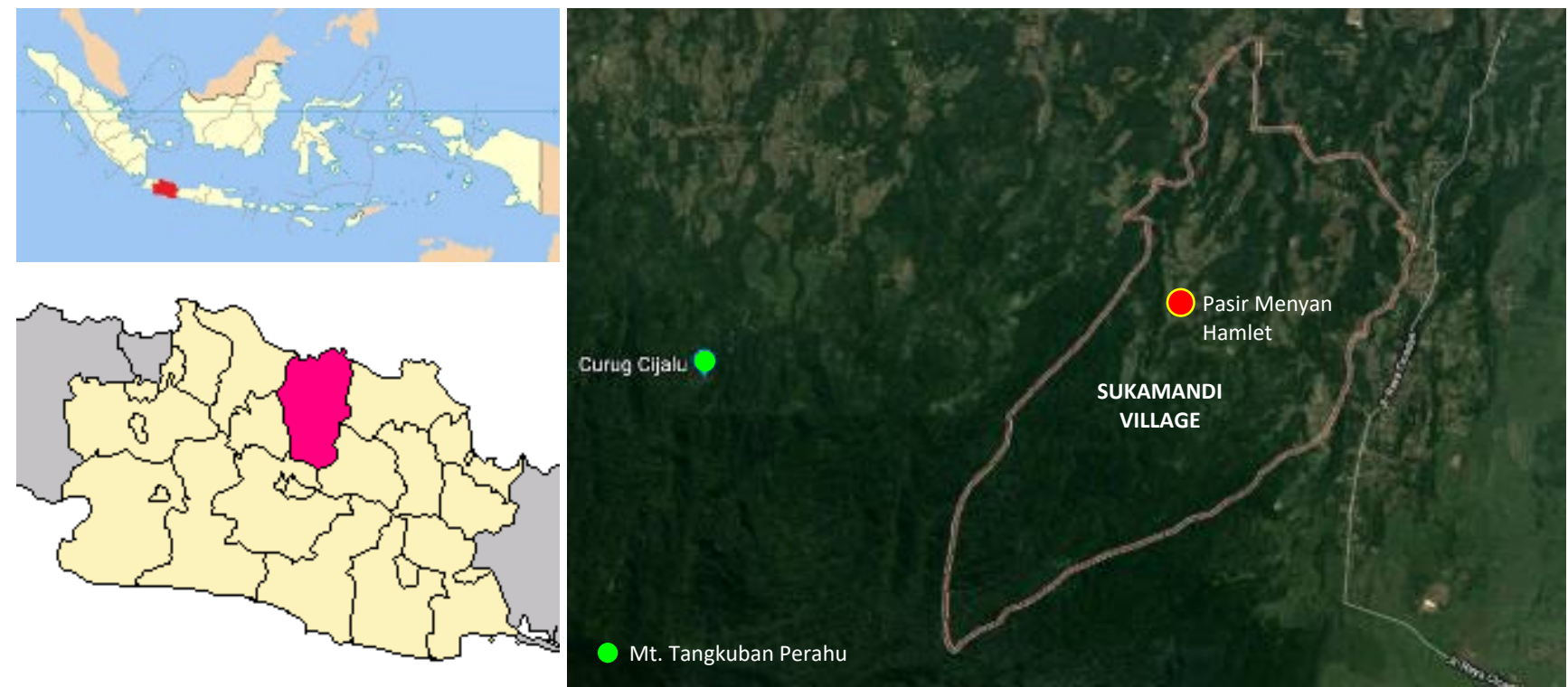

Figure 1. Map of Pasir Menyan Hamlet, Sukamandi Village, Sagalaherang Sub-district, Subang District, West Java, Indonesia (107³7’27,22' E; 6044”45,26' S) 
Table 1. Population, livelihood, and education of people in Pasir Menyan Hamlet, Sukamandi Village, Subang District, West Java, Indonesia

\begin{tabular}{llll}
\hline Parameters & Male & Female & Total \\
\hline $\begin{array}{l}\text { Population } \\
\quad \text { No of households; HH }\end{array}$ & & & \\
$\quad$ Total of individual number & 1,595 & 1,557 & 3,121 \\
& & & \\
Education & & & \\
$\quad$ Primary school & 6,38 & 6,36 & 1,274 \\
$\quad$ Junior high school & 275 & 247 & 522 \\
Senior high school & 208 & 205 & 413 \\
Diploma 1 & 4 & 3 & 7 \\
Diploma 2 & 3 & 3 & 6 \\
Diploma 3 & 8 & 9 & 17 \\
Undergraduate & 29 & 31 & 60 \\
& & & \\
Livelihood & & & \\
Farmer & 411 & 375 & 786 \\
Farmworkers $\square$ & 420 & 381 & 801 \\
Trader & 24 & 22 & 46 \\
$\quad$ Military (TNI) & 13 & - & 13 \\
Government employees & 24 & 22 & 46 \\
\hline
\end{tabular}

In general, the topography of this area is surging with steep slopes $30-50 \%$. The altitude of the research site is at 1,150-2,684 $\mathrm{m}$ above sea level (asl.). Based on the classification of Schmidt and Ferguson, the climate in this region has category of climate $\mathrm{B}$ with an average rainfall of 2,000-3,000 mm/year, with temperatures at $15^{\circ}-29^{\circ} \mathrm{C}$, and an average humidity of $45-97 \%$ (BBKSDA West Java 2016). In the western, eastern and southern regions of the village are bordered by Cikujang Village, Tangkuban Perahu Mount Forest, Dayeuh Kolot village, and Ciater Village, respectively. The Sukamandi Village has total area 727 ha. The total population of this village was recorded 3,152 peoples belonging to 1,121 households in 2017 . Education of people in Sukamandi Village was documented in dominant primary school, while the main livelihood of people as farmers and farm workers (Table 1) (Village Statistical Data 2017).

\section{Procedure}

The method used in this study was mixed-method, qualitative and quantitative with the ethnobotanical approach (Martin 1995; Albuquerque et al. 2014; Iskandar 2018). Some techniques, namely observation, semistructured interviews, structured interviews, and survey tree ferns were carried out. The observation was done to get information of the local condition of the forest environment of the study area. Also, the observation was undertaken to observations some activities of rural people of Pasir Menyan Hamlet, particularly in relation to the utilization of tree ferns. Semi-structured interviews were carried with competent informants or local experts, including old farmers, informal leaders, formal village leaders, forestry staffs, firewood and ornamental plant collectors, and village middlemen that informant was given in a series of general questions on species diversity, local habitat conditions, utilization, trading, and traditional conservation of tree ferns. Some questions were prepared in advance and some of which arise naturally during the curse of conservation (Martin 1995). While structured interview, it was undertaken with respondents that were randomly selected. Determination of respondent number was carried out by "simple random sampling". Respondents selected in this study were chosen the head of the family $(\mathrm{HH})$ (Newing 2011), the amount of which was determined by the Lynch (1995) formula, as follows:

$$
n_{t}=\frac{N_{t} \cdot z^{2} \cdot P(1-P)}{N_{t} \cdot d^{2}+Z^{2} \cdot P(1-P)}
$$

Where:

$n$ : The total number of respondents

P: The biggest probability proportion $(0.50)$

$N$ : Total population (household number): sampling error $(0.10)$

$Z$ : Normal variable value (1.96)

Based on the total number of household heads recorded at 1,821 , therefore the number of respondents needed for this study can be calculated using the Lynch (1995) formula as follows:

$$
\begin{aligned}
n= & 1821(1.96) 2 .(0.5) \cdot(1-0.5) \\
& 1821 .(0.1) 2+(1.96) \cdot(0.5) \cdot(1-0.5) \\
n= & 91.23=91 \text { households }
\end{aligned}
$$

\section{Survey of tree ferns diversity}

The direct survey was conducted by visited some potential habitats of tree ferns in the study are. Moreover, to identify species of tree ferns was carried out by taking pictures and making specimens of tree spikes herbaria. Some references, including Flora Malesiana, Ferns of Malaysia in Color (Piggott 1988), Ferns Grower's Manual (Hoshizaki and Moran 2001), Encyclopedia of Fern Garden (Olsen 2007), and plants.jstor.org; www.um. were used to identify species of tree ferns.

\section{Data analysis}

Local knowledge data on tree ferns were analyzed using qualitative and quantitative descriptive methods. Qualitative descriptive is used to describe data from interviews, whose data analysis process includes data reduction (selection, simplification, and making abstraction), and data presentation. Data in the form of a collection of information that is grouped and analyzed first until finally presented in the narrative form supported by pictures, tables, and charts, to obtain conclusions. Furthermore, content analysis techniques are performed on secondary data that are relevant to the purpose of the study and compare with data from structured interviews (Newing 2011; Creswell 2016; Iskandar 2018). Quantitative description analysis is used to describe data derived from structured interview data, which is then analyzed with simple statistics (Steel and Torrie 1991; Iskandar 2018). 
Percentage of answers $(\%)=(n / N) \times 100 \%$

Where:

$\mathrm{n}$ : number of respondents who choose a particular answer $N$ : Total number of respondent's answers

Moreover, the data was presented in the form of graphs and diagrams, which are equipped with data descriptions that compare secondary data with the relevant conceptual framework, and made narrations with descriptive analysis.

\section{RESULTS AND DISCUSSION}

\section{Diversity of tree ferns based on local knowledge}

Based on semi-structured interviews, 8 landraces of tree fern were recognized by the informant. The local names of tree ferns in Pasir Menyan Hamlet, which are all Sundanese inhabitants are as follows: pakis tihang, pakis sieur, bagedor, pakis minyak, pakis payung, pakis cempor, pakis bulu, and sijabrig (Table 2). Based on the results of interviews with local people, all species of tree ferns are called pakis tihang because of their adult trunk like tree trunk (trunk: tihang in Sundanese language). In general, the local name of tree ferns is based on its morphological characteristics, for example pakis sieur for tree ferns that has a new branching from the trunk (Sieur in Sundanese meaning a bud). Naming for pakis payung because this type has a canopy like an umbrella (payung in Sundanese meaning an umbrella), while naming of pakis bulu or sijabrig, because the leaf tops and base of the leaves have long and thick fur (jabrig).

In Bali, Cyathea latebrosa, Cyathea contaminans, and Dicksonia blumei are called lemputu, lempunah, and paku kidang respectively. Likewise, in Central and East Java $C$. contaminans are called paku arjuno, pakis galar or pakis oleng. It can be concluded that the name of the local tree ferns is dependent on the origin of the region.

However, it is not impossible that there are differences in the names of tree ferns in the same area. The local name of tree ferns at Pasir Menyan Hamlet is varied. Most of the respondents said that tree ferns were ferns for the four species are shown in Table 2. C. latebrosa has two local names, while other species each have three local names.

\section{Local knowledge base on age and education levels}

Based on structured interview with respondents that are categorized by ages and education, on local knowledge on tree fern species, the results are shown in Figure 2.

It can be seen from Figure 2, the knowledge of local names of tree ferns has increased from the ages of 20-29, 60-69 and 50-59 years. However, for the age 60-69 years tended to decrease, it is predicted the old people are not properly memory on tree ferns (Iswandono et al. 2015). This result of research is similar to that of discussed by Lizarralde (2004), who conducted a study on ethnobotany on forest conservation in Bari, Venezuela, Latin America. Based on his research, it can be revealed that botanical knowledge of indigenous people varies from person to persons due to factors, such as age, subsistence practice, gender, and bilingualism. Interns of age, people older than 39 years recognize a higher percentage local knowledge on forest trees compared to that of children and younger people.

Table 2. Local and scientific names of tree ferns recorded in Pasir Menyan Hamlet, Sukamandi Village, Subang District, West Java, Indonesia

\begin{tabular}{|c|c|c|c|c|c|c|c|c|}
\hline Species & 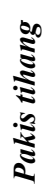 & 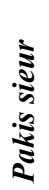 & 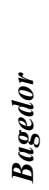 & 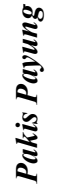 & 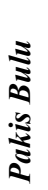 & 'ָ) & 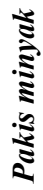 & 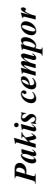 \\
\hline $\begin{array}{l}\text { Cyathea contaminans (Wall. ex } \\
\text { Hook.) Copel. }\end{array}$ & 10 & & 50 & & & & 7 & \\
\hline $\begin{array}{l}\text { Cyathea latebrosa (Wall. ex } \\
\text { Hook.) Copel. }\end{array}$ & 30 & 51 & & & & & & \\
\hline $\begin{array}{l}\text { Cyathea orientalis (Kunze) } \\
\text { Moore }\end{array}$ & 10 & & & 10 & & & & 46 \\
\hline $\begin{array}{l}\text { Dicksonia blumei (Kunze) } \\
\text { Moore }\end{array}$ & 12 & & & & 30 & 10 & & \\
\hline
\end{tabular}

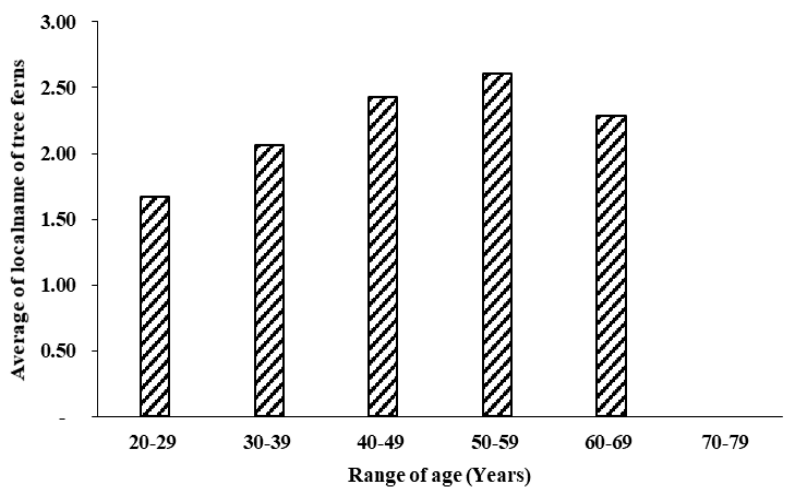

A

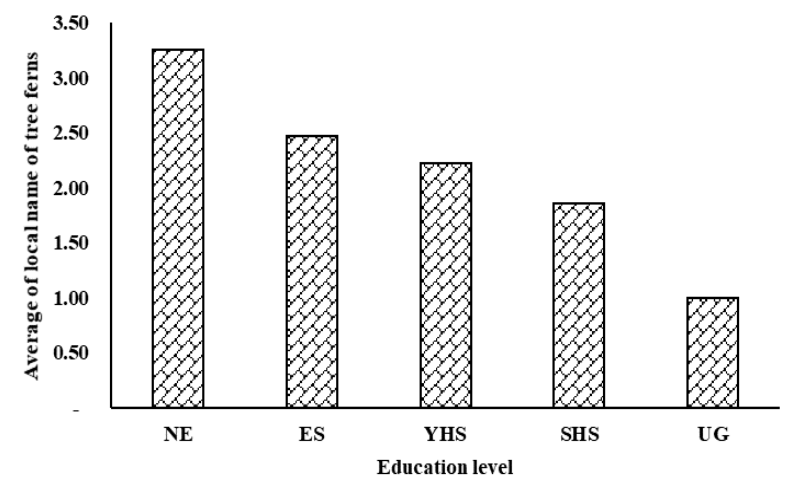

B

Figure 2. Average of knowledge of local names of tree ferns based on; (A) age range and (B) respondent's education level. Note: NE= no-education, ES= elementary school, JHS= Junior high school, $\mathrm{SHC}=$ Senior high school, and UG= Undergraduate 
Based educational background of respondents, the respondent with a non-primary school background have higher local knowledge than that elementary, middle, high school and undergraduate university (Figure 2). In other words, the high-level formal education in the rural area is not guaranteed to have high knowledge of tree ferns. Because local knowledge has predominantly obtained from individual personal experiences with local environments, including forest ecosystems (Iskandar and Iskandar 2005; Iskandar 2012).

Based on some studies on local knowledge, nowadays, declining of the local knowledge among young age range also occurs in other regions, such as: Banten Baduy (Hidayati 2013), Manggarai Tribe, Ruteng Mountains,
Manggarai District, East Tenggara (Iswandono et al. 2015), Communities around Wanagama Education Forest, Yogyakarta (Romdhoni et al. 2015) due to young generation has predominantly interested learning on Western knowledge instead of local knowledge.

\section{The diversity of tree ferns based on botanical knowledge}

Based on the field survey 4 species of tree ferns were recorded in the study area, at the forest of Tangkuban Perahu Mountain, Subang, West Java. Validation of species names refers to the reference book, which is summarized in Table 3, while the habitus is shown in Figure 3.

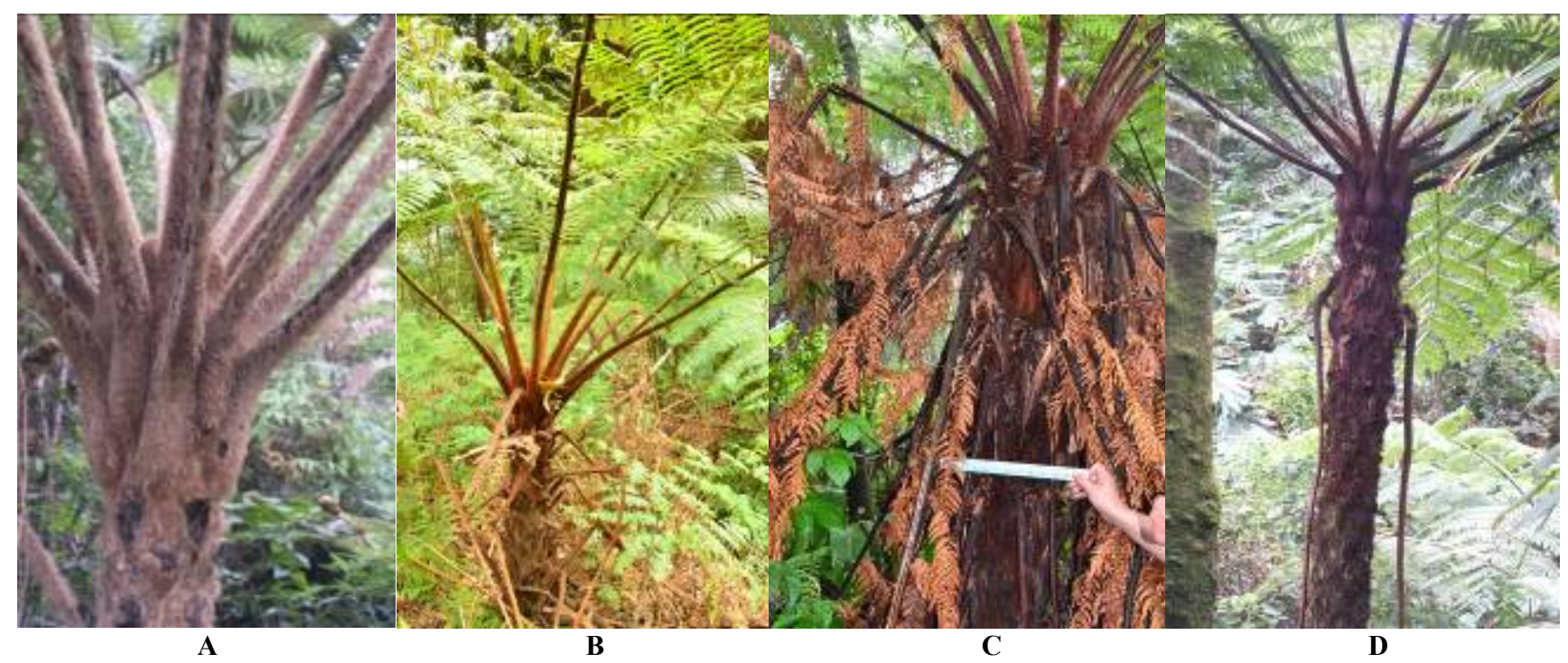

Figure 3. Species of tree ferns in the study location of Pasir Menyan Hamlet, Sukamandi Village, Subang District, West Java, Indonesia. A. Cyathea contaminans; B. Cyathea latebrosa; C. Cyathea orientalis; D. Dicksonia blumei

Table 3. Morphology of Cyathea contaminans, Cyathea latebrosa, Cyathea orientalis, and Dicksonia blumei

\begin{tabular}{|c|c|c|c|c|}
\hline \multirow[b]{2}{*}{ Plant organ } & \multicolumn{4}{|c|}{ Species } \\
\hline & $\begin{array}{c}\text { Bagedor } \\
\text { (Cyathea contaminans) }\end{array}$ & $\begin{array}{c}\text { Pakis Sieur } \\
\text { (Cyathea latebrosa) }\end{array}$ & $\begin{array}{c}\text { Pakis Cempor } \\
\text { (Cyathea orientalis) }\end{array}$ & $\begin{array}{c}\text { Pakis Bulu } \\
\text { (Dicksonia blumei) }\end{array}$ \\
\hline \multicolumn{5}{|l|}{ Trunk } \\
\hline Height & $\geq 10 \mathrm{~m}$ & $\geq 10 \mathrm{~m}$ & $\leq 10 \mathrm{~m}$ & $\leq 8.5 \mathrm{~m}$ \\
\hline Shape & $\begin{array}{l}\text { Straight trunk, without } \\
\text { branches }\end{array}$ & $\begin{array}{l}\text { Most trunks are curved } \\
\text { with many branches }\end{array}$ & $\begin{array}{l}\text { Straight trunk, without } \\
\text { branches }\end{array}$ & $\begin{array}{l}\text { Straight trunk, without } \\
\text { branches }\end{array}$ \\
\hline Fiber & $\begin{array}{l}\text { Have thick fiber up to } 0.5 \mathrm{~m} \text {, } \\
\text { decreasing, to the trunk top. }\end{array}$ & $\begin{array}{l}\text { Rarely fibers on the } \\
\text { entire trunk }\end{array}$ & $\begin{array}{l}\text { The whole trunk was } \\
\text { covered with thick fibers }\end{array}$ & $\begin{array}{l}\text { The whole trunk was } \\
\text { covered with quite fibers }\end{array}$ \\
\hline Diameter & $\leq 20 \mathrm{~cm}$ & $\leq 13 \mathrm{~cm}$ & $\leq 13 \mathrm{~cm}$ & $\leq 15 \mathrm{~cm}$ \\
\hline \multicolumn{5}{|l|}{ Leaf } \\
\hline Stipe & $\begin{array}{l}\leq 60 \mathrm{~cm} \text {, sturdy, big and sharp } \\
\text { spines }\end{array}$ & $\begin{array}{l}\text { More than } 60 \mathrm{~cm} \text {, } \\
\text { sturdy, blunt spines. }\end{array}$ & $\begin{array}{l}\leq 60 \mathrm{~cm} \text {, sturdy, small } \\
\text { and sharp spines }\end{array}$ & $\begin{array}{l}\leq 60 \mathrm{~cm} \text { sturdy, browns } \\
\text { hair, }\end{array}$ \\
\hline Lamina & $\leq 3.5 \mathrm{~m}$ & $\leq 2.1 \mathrm{~m}$ & $\leq 2.1 \mathrm{~m}$ & $\leq 1.5 \mathrm{~m}$ \\
\hline $\begin{array}{l}\text { Spines on the } \\
\text { basal leaf stalk }\end{array}$ & Sharp spines up to $0.5 \mathrm{~cm}$ & $\begin{array}{l}\text { Blunt spines, less than } \\
0.5 \mathrm{~cm}\end{array}$ & $\begin{array}{l}\text { Sharp spines less than } \\
0.5 \mathrm{~cm}\end{array}$ & Without spines \\
\hline Sorus & $\begin{array}{l}\text { 6-8 pairs of large sorus, under } \\
\text { the leaves. }\end{array}$ & $\begin{array}{l}5-7 \text { pairs of small } \\
\text { sorus, under the leaves }\end{array}$ & $\begin{array}{l}\text { 5-7 pairs of small sorus, } \\
\text { under the leaves }\end{array}$ & $\begin{array}{l}\text { Sorus is located under of } \\
\text { the leaf }\end{array}$ \\
\hline
\end{tabular}




\section{Utilization of tree ferns}

Based on an interview with respondents, tree ferns have been used for various purposes, including ornamental plants, growing media, handicraft, vegetables, and tool of games (Figure 4).

The local knowledge of the use of tree ferns for all categories almost similar, except as vegetables and tool games, indicating that this knowledge has been going on for a long time and is maintained. The uses of each species of tree ferns are presented in Table 4.

\section{Tree ferns as ornamental plants}

The species of tree ferns that were planted in the yard were no different from the species of tree ferns that were planted in the gardens of hotels or villas. The species of tree ferns are bagedor (C. contaminans), pakis cempor (Cyathea orientalis), and pakis bulu (D. blumei). Of the three species, bagedor (C. contaminans) is a species that is widely used, after that is pakis bulu (D. blumei). It usually is taken from their natural habitat in the form of seedlings (less than $10 \mathrm{~cm}$ in diameter and $1.5 \mathrm{~m}$ in height), then planted in place as needed (Figure 5). Use of this type has been reported by Sastrapradja et al. (1978), that the types of tree ferns are used for raw materials for sculpture, ornamental plants, home or hotel decoration poles.

The species of tree ferns used as a wall decoration for the building is bagedor (C. contaminans). According to most informants, this species has a unique motif on the inside if the outer layer is shriveled in themes like batik or like a python snake. The middle part of the ferns (ati=local name) is usually discarded, the remaining stems are dried and ready for use as wall hangings (Figure 6). Other purposes, this bagedor stem is cut across $30 \mathrm{~cm}$ long or 50 $\mathrm{cm}$ long at the request then after that, each is cut in parallel.

\section{Tree ferns as plant growing media}

Pakis sieur ( $C$. latebrosa) is widely used for orchid growing media because the fibers are not dense (local language $=$ hampos). This fiber character causes orchids to grow well. This planting medium is made by cutting a rectangular section with a size of $1 \times 10 \times 20 \mathrm{~cm}^{3}$ (Figure 7). The base of the stem fibers can also be used for growing various ornamental plants, by inserting fibers that have been broken down into pots or polybags. The similar use of this type has been reported by Harnum et al. (2014), that pakis sieur is widely used as a medium for growing other plants, especially orchids.

\section{Tree ferns as handicraft}

Bagedor (C. contaminans) is widely used as a handicraft, because the fibers covering the stems are thin compared to other species. As mentioned the patterned parts such as batik motifs or like python snakes on the base of the leaf stalks that have been peeled off (Figure 8). Use of this type has been reported by Sastrapadja et al. (1978) that this type is widely used for pot and ashtray raw materials.

\section{Use of tree ferns as raw material for game tool}

The use of other tree ferns is for games, and the people call it the name Lodong and for soccer material. Species of tree ferns that are widely used for this game are bagedor $(C$. contaminans) and pakis cempor (C. orientalis). The part that is used is the stem pith, and this part is removed from

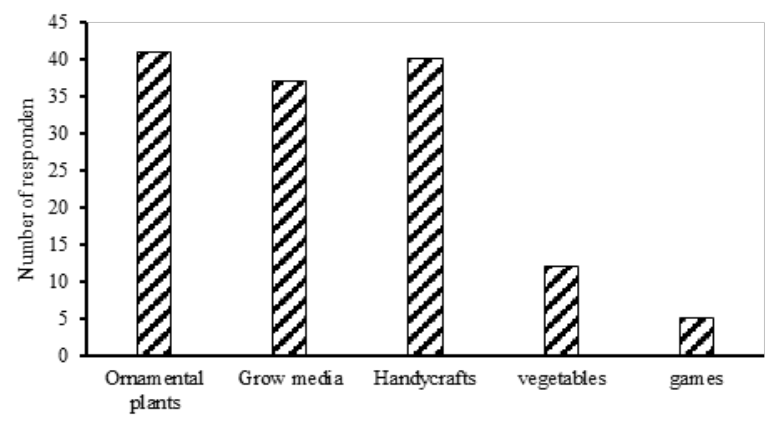

Figure 4. Some use of tree ferns at Pasir Menyan Hamlet, Sukamandi Village, Subang District, West Java, Indonesia

Table 4. Uses of tree ferns at Pasir Menyan Hamlet, Sukamandi Village, Subang District, West Java, Indonesia

\begin{tabular}{|c|c|c|c|c|c|}
\hline \multirow[b]{2}{*}{ Species } & \multicolumn{5}{|c|}{$\begin{array}{l}\text { Respondents local knowledge } \\
\text { answers to the use of tree ferns at } \\
\text { Pasir Menyan Hamlet (person) }\end{array}$} \\
\hline & 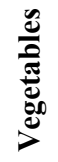 & 叟 & 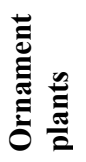 & 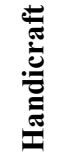 & 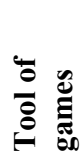 \\
\hline Cyathea contaminans & 5 & 20 & 18 & 40 & 5 \\
\hline Cyathea latebrosa & 7 & 17 & - & - & - \\
\hline Cyathea orientalis & - & - & 10 & - & - \\
\hline Dicksonia blumei & - & - & 13 & - & - \\
\hline
\end{tabular}

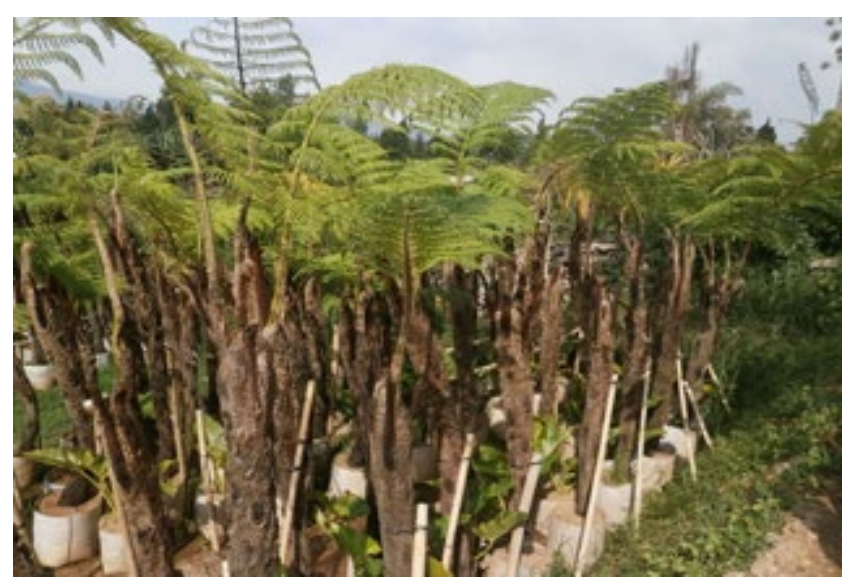

Figure 5. Tree ferns that are ready to be planted in the yard or garden collection 


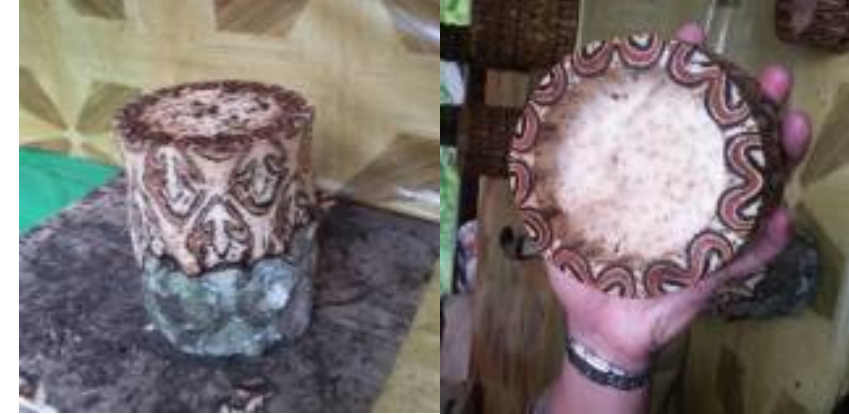

Figure 6. Tree ferns of Cyathea contaminans species cut across transverse show motifs such as batik or python snakes.

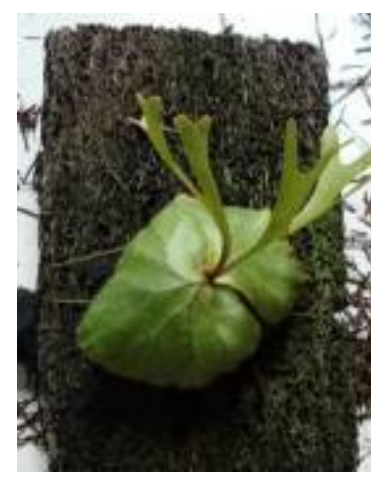

A

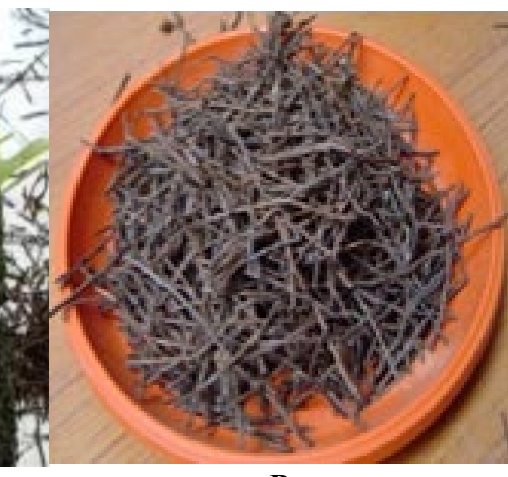

B
Figure 7. A. Tree ferns that have been cut as growing media for orchid plants; B. The fiber of the base of the stem for growing ornamental plants

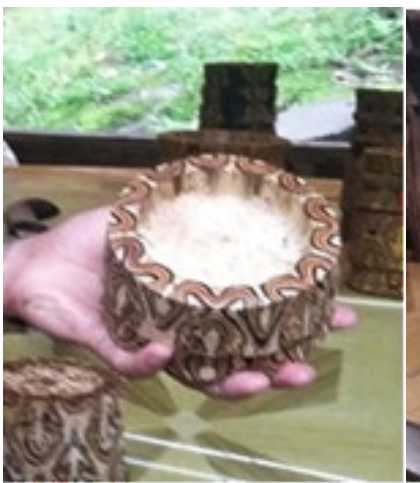

A

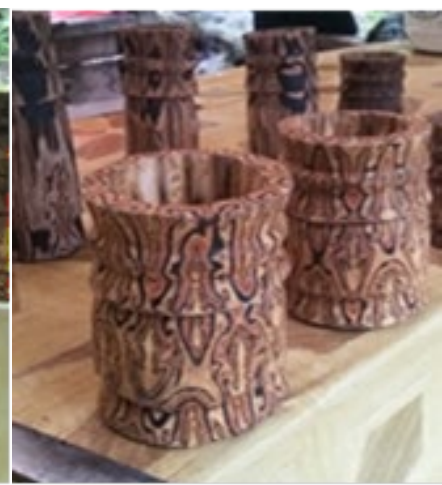

B
Figure 8. Trunk of Cyathea contaminans as decorative material such as: A. Flower pots, B. Cigarette ashtrays

the trunk and then in a round shape like a ball. Unfortunately, lodong and soccer ball made of tree ferns were no longer found at this hamlet because the game had not been done for a long time. Now the day, bamboo has replaced tree ferns as raw material for each lodong as well as for soccer ball. At present, the use of tree ferns as a material for making lodong has been replaced with bamboo, possibly because of the reduced of its population.

\section{Traditional conservation of tree fern}

Based on semi-structured interview with informants, in general, Sundanese people have traditionally practiced on forest conservation. This conservation concept has been expressed as traditional prohibition or taboo that is called as pamali. For example, rural people of Sundanese people have prohibited to cut forest located in the river banks (sisi walungan in Sundanese language), in the valleys (lamping), that the conservation areas are suitable places for growing tree ferns (Iskandar 2009). According to informants, some local people mentioned the tradition pamali coming to these places especially while taking tree ferns. Pamali means the prohibition not to visit the area is related to the existence of a trust that can cause harm if violated. Indirectly this tradition is an attempt to protect the existence of tree ferns, especially those in place. However, most of the local people have no longer held this belief, and it is possible that this is one of the uncontrolled taking of tree ferns and causing a decline in population and the number of species.

It can be concluded that it was recorded 8 landraces of tree fern were recognized by informants, namely pakis tihang, pakis sieur, bagedor, pakis minyak, pakis payung, pakis cempor, pakis bulu, and sijabrig. In terms of local knowledge on tree ferns, people with ages 50-59 years old recorded a right a higher percentage of tree ferns than the children and younger people. Regarding education, the result showed that a low level of education had the highest level of knowledge of local names and utilization of tree ferns as vegetables, ornamental plants, growing media, and for handicrafts because of they still intensive interaction with forest ecosystem and tree ferns. On the basis conservation of tree ferns, the rural people of Sundanese people have the tradition to prohibit (pamali) to cut forest on the river bank, open slopes, closed forests, damaged forest areas, and in the valleys.Also, traditional conservation practice on tree ferns has recorded. For example, rural people of Pasir Menyan Hamlets have traditional prohibited (pamali) to the opened sacred forest, including to take of tree ferns.

\section{ACKNOWLEDGEMENTS}

The authors would like to thank the Ministry of Research, Technology, and Higher Education for funding through the Domestic Postgraduate Education Scholarship. Also, authors would like to thank village leader staff, informants, and respondents who have kindly assisted the field research. This paper publication is endorsed by ALG (Academic Leadership Grant) of Prof. Johan Iskandar that is financially supported by Universitas Padjadjaran. In this opportunity, we would like to thank Rector of Universitas Padjadjaran, Sumedang, Indonesia who supports the ALG program. We would like to thank Dean of Faculty of Mathematics and Natural Sciences, Head of Department of Biology who have been supporting this publication. 


\section{REFERENCES}

Albuquerque UP, Cunha LVFVC, Lucena RPL, Alves RRN. (eds). 2014. Methods and Techniques in Ethnobiology and Ethnoecology. Springer Science and Business Media, New York.

Anderson EN, Pearsal DM, Hunn ES, Turner JN. 2011. Ethnobiology. John Wiley \& Sons Inc., New Jersey.

BBKSDA West Java. 2016. Ministry of Forestry Statistics of 2016. Ministry of Forestry of the Republic of Indonesia, Jakarta. [Indonesian]

Creswell JW. 2016. Research Design: Qualitative, Quantitative and Mixed Methods Approach. Penerbit Pelajar, Yogyakarta.

Efendi WW, Hapsari FNP, Nuraini Z. 2013. Study diversity of the ferns in the tourism area of Coban Rondo, Malang District. Cogito Ergo Sum 2 (3): 173-188.

Handayani T, Hartini S. 2003. Perkecambahan spora paku pohon (Cyathea contaminans (Wall. ex Hook.) Copel) pada berbagai media tumbuh. BioSMART 5(2): 111-114.

Hidayati S. 2013. Analysis of the Application of Ethnobotany Knowledge of the Baduy Community in Food Security. [Thesis]. Bogor Agricultural University, Bogor.

Holtum RE. 1965. Tree-ferns of the genus Cyathea in Java. Reinwardtia 7(1): $5-8$.

Hoshizaki BJ, Moran RC. 2001. Fern Grower's Manual. Timber Press Inc., Oregon.

Iskandar J. 2009. Conservation of Mandala area and biodiversity undertook among Baduy Community. In Soedjito H, Purwanto Y, Sukara E. (eds), Natural Sacred Sites: The Role of Culture in Biodiversity Conservation. Yayasan Obor, Jakarta. [Indonesian].

Iskandar J. 2012. Ecology of Baduy Farming: Sustainable Indigenous Forest Management. PT. Alumni, Bandung

Iskandar J. 2018. Ethnobiology, Ethnoecology, and Sustainable Development. PT. Plantaxia, Yogyakarta

Iskandar J, Iskandar BS. 2005. Alternative Medicine of Baduy Community. Humaniora, Bandung [Indonesian].

Iswandono E, Muhammad Zuhud EA, Hikmat A, Kosmaryandi N. 2015. Ethnobotany knowledge of the Manggarai tribe and its implications for the use of forest plants in the Ruteng mountains. Indonesian Journal of Agricultural Science 20(3): 171-181.

Jacobs M. 1981. The Tropical Rain Forest: A First Encounter. SpringerVerlag, Berlin Heidelberg New York, London, Paris, Tokyo.

Large MF, Bragins JE. 2004. Tree Ferns. Timber Press, Portland Cambridge.

Lizarralde M. 2004. Indigenous knowledge and conservation of the rainforest: Ethnobotany of Bari of Venezuela. In: Carlson TJS, Maffi L. (eds), Ethnobotany and Conservation of Biocultural Diversity. The New York Botanical Garden Press, New York. $\square$
Lynch OJ. 1995. Balancing Act: Community-based Forest Management and International Law in Asia and the Pacific. World Resources Institute, Bogor.

Martin GJ. 1995. Ethnobotany: A Methods Manual. Chapman \& Hall, London.

Newing H. 2011. Conducting Research in Conservation. Routledge, Simultaneously published, USA and Canada.

Olsen S. 2007. Encyclopedia of Garden Ferns. Timber Press Inc., Oregon.

Pei SJ. 2013. Ethnobotany and sustainable use of biodiversity. Plant Diversity Resources 35(4): 401-406.

Partasasmita R. 2009. Community Ecology of Frugivorous Bird: Eating Ecology and Shrub Succession in Panaruban, Subang [Dissertation]. Bogor Agricultural University, Bogor. [Indonesian]

Partasasmita R, Mardiastuti A, Solihin DD, Widjajakusumah R, Prijono SN. 2016. Frugivorous bird characteristic of seed disperser in shrubland tropical forest. Biodiversitas 18: 263-268.

Permana CE. 2010. Local Wisdom of the Baduy Community in Disaster Mitigation. Wedatama Widya Sastra, Jakarta.

Piggott AG. 1988. Ferns of Malaysia in Colour. Tropical Press SDN. BHD, Kuala Lumpur.

Praptosuwiryo TNg, Pribadi DO, Puspitaningtyas DM, Hartini S. 2011. Inventory the tree fern genus Cibotium of Sumatera: ecology, population size, and distribution in Nort Sumatera. Biodiversitas 12(4): 204-211.

Rahayu M, Susiarti S, Purwanto Y. 2006. Study of the utilization of nontimber forest vegetation by local society at PT. Wira Karya Sakti Sungai Tapa conservation area - Jambi. Biodiversitas 8 (1): 73-78. [Indonesia]

Ramırez-Barahona S, Luna-Vega I, Tejero-Diez D. 2011. Species richness, endemism, and conservation of American tree ferns (Cyatheales). Biodiversity and Conservation 20: 59-72.

Romdhoni H, Reginald Y, Nurhadi M, Octaviani R, Sedayu A. 2015. Socio-educational knowledge of ethnobotany surveys of ferns in communities around Wanagama education forest, Yogyakarta. Prosiding Seminar Nasional Masyarakat Biodiversitas Indonesia 1 (8): 2044-2050

Soepartinah I. 2013. Study of Lumut Janggut (Usnea spp.) In East Priangan. [Dissertation], Padjadjaran University, Bandung. [Indonesian]

Srivastava K. 2007. Ethnobotanical studies of some important ferns. Ethnobotany Leaf 11: 164-172.

Steel RGD, Torrie JH. 1991. Principles and Procedures of Statistics. Gramedia, Jakarta. [Indonesian].

Tjitrosoepomo G. 2001. Plant Taxonomy (Schizophyta, Thallophyta, Bryophyta, Pteridophyta). Gadjah Mada University Press., Yogyakarta. [Indonesian]

van Steenis CGGJ. 2006. The Mountain Flora of Java. 2nd ed. E.J. Brill, Leiden. $\square$

Whitten T, Soeriaatmadja RE, Afiff SA. 1999. Ecology of Java and Bali. Prehallindo, Jakarta. [Indonesian] 